\title{
Organophosphates and monocyte esterase deficiency
}

\author{
E McClean, H Mackey, G M Markey, T C M Morris
}

\begin{abstract}
Aims-To examine the possibility that monocyte esterase deficiency (MED) could be caused by exposure to organophosphates.

Methods-Pseudocholinesterase, paraoxonase and arylesterase activities were measured in the serum and acetylcholinesterase activity was measured in the red cells of a group of monocyte esterase deficient subjects and compared with the enzyme activities of a control group of monocyte esterase positive subjects.

Results-No significant difference was found between the enzyme activities of the monocyte esterase deficient group and the control group for any of the esterases investigated.
\end{abstract}

Conclusion-Current or recent exposure to organophosphorus is not the cause of MED.

(f Clin Pathol 1995;48:768-770)

Keywords: Monocyte esterase deficiency, organophosphates, neoplastic disease.

Monocyte esterase is an enzyme unique to cells of monocytic lineage. ${ }^{1}$ It is characterised in vitro by a positive reaction to the non-specific esterase cytochemical stain ${ }^{2}$ based on its ability to de-acylate napthyl acetate or butyrate and also identified by its specific isoelectric focus on polyacrylamide gels. ${ }^{3}$ Using an automated cytochemistry analyser, it has been previously demonstrated that monocyte esterase deficiency (MED; defined as the consistent presence of $>85 \%$ esterase negative monocytes in a subject's peripheral blood) occurs in $0.8 \%$ of blood donors (four of 474) and significantly more frequently in patients with immunoproliferative $(7.4 \% ; 18$ of 243$)$ and gastrointestinal neoplastic disease $(10 \% ; 12$ of 120$) .{ }^{45}$ A $35 \%$ incidence of MED has also been shown in 15 families of patients with $\mathrm{MED}^{467}$ but a genetic basis for the familiality has not been found as yet. Linkage of MED to the chromosomal site $(16 \mathrm{q} 3: 22.1)^{8}$ of a gene for monocyte esterase, HMSE1, has been excluded (manuscript in preparation; Dr K Ennis and Dr A Hughes, Department of Medical Genetics, Belfast City Hospital).

Lee and Waters, ${ }^{9}$ using the same make of cytochemistry analyser, showed that the activity of monocyte esterase was diminished in blood samples taken in the presence of traces of organophosphate insecticide and subsequently extreme exposure to organophosphates was demonstrated to diminish enzyme activity in vivo, also using the same analyser. ${ }^{1011}$ Monocytes with either constitutional ${ }^{12}$ or acquired ${ }^{1314}$ esterase deficiency manifest impaired tumour cell killing in vitro. Study of the occupational activity of subjects with MED has not revealed any evidence of exposure to organophosphates. Nevertheless, because of the association of the deficiency with malignant neoplastic disease and the suspicion that exposure to organophosphate might be a factor in lymphomagenesis, ${ }^{15}$ we felt it was important to prove/ disprove any possibility of current exposure in our MED cohort, by examining other esterases, red cell cholinesterase and serum pseudocholinesterase, the activities of which are reduced in the presence of organophosphates and also to compare paraoxonase activities and phenotypes in normal subjects and in those with MED.

\section{Methods}

Blood was collected from 11 subjects with MED (identified in previous studies ${ }^{467}$ and who continued to manifest the deficiency) and from 11 subjects who had normal monocyte esterase activity. Serum was stored at $-70^{\circ} \mathrm{C}$ and analysed for paraoxonase activity, with and without $\mathrm{NaCl}$ stimulation. The defrosted samples were then stored at $4^{\circ} \mathrm{C}$ and analysed for pseudocholinesterase and arylesterase activity within 48 hours. Two of the samples from the MED group were insufficient for pseudocholinesterase estimation. The paraoxonase phenotype was determined using the values obtained for paraoxonase and arylesterase activity. Washed red cells from the subjects with MED were stored at $-20^{\circ} \mathrm{C}$ for analysis of red cell acetylcholinesterase activity.

\section{MATERIALS}

Paraoxon*, phenylacetate, 4-nitrophenylacetate, acetyl-( -methyl)thiocholine and 5,5'dithio-bis(2-nitrobenzoic acid) were all supplied by Sigma Chemical Company Ltd. (Poole, Dorset, UK). The serum cholinesterase kit was supplied by Boehringer Mannhein UK (Lewes, Sussex, UK).

* Paraoxon is a very hazardous substance and must be handled with extreme care, use of a fume cupboard and protective clothing when making up the substrate is mandatory. However, it is completely inactivated in strong alkali $(50 \% \mathrm{NaOH})$ which should be used for soaking all consumables used in the assay before disposal. 
Table 1 Comparison of cholinesterase and paraoxanase activities in subjects with MED and controls. Values expressed as range (median; quartiles)

\begin{tabular}{|c|c|c|c|}
\hline & $M E D$ & Controls & $p$ \\
\hline $\begin{array}{l}\text { Basal paraoxonase activity } \\
(\mathrm{nmol} / \mathrm{min} / \mathrm{ml}) \\
(\mathrm{n}=11,11)\end{array}$ & $\begin{array}{l}89-227 \\
(155 ; 120,207)\end{array}$ & $\begin{array}{l}34-295 \\
\left(122^{*} ; 66,255\right)\end{array}$ & 0.92 \\
\hline $\begin{array}{l}\text { Salt stimulated paraoxonase } \\
\text { activity }(\mathrm{nmol} / \mathrm{min} / \mathrm{ml}) \\
(\mathrm{n}=11,11)\end{array}$ & $\begin{array}{l}91-477 \\
(350 ; 114,458)\end{array}$ & $\begin{array}{l}60-452 \\
\left(200^{*} ; 96,428\right)\end{array}$ & 0.32 \\
\hline $\begin{array}{l}\text { Pseudocholinesterase } \\
(\mathrm{KU} / \mathrm{l}) \\
(\mathrm{n}=9,11)\end{array}$ & $\begin{array}{l}4 \cdot 4-6 \cdot 9 \\
(6 \cdot 2 ; 5 \cdot 3,6 \cdot 8)\end{array}$ & $\begin{array}{l}3 \cdot 4-7 \cdot 0 \\
(5 \cdot 3 ; 4 \cdot 0,6 \cdot 0)\end{array}$ & $0 \cdot 13$ \\
\hline $\begin{array}{l}\text { Acetylcholinesterase } \\
(\mathrm{KU} / 1) \\
(\mathrm{n}=11,90)\end{array}$ & $\begin{array}{l}7 \cdot 0-9 \cdot 4 \\
(8 \cdot 1 ; 7 \cdot 2,9 \cdot 0)\end{array}$ & $\begin{array}{l}5 \cdot 4-11 \cdot 9 \\
(8 \cdot 1 ; 7 \cdot 5,8 \cdot 8)\end{array}$ & 0.86 \\
\hline
\end{tabular}

$\mathrm{n}=$ number of subjects in each group (MED, control).

* Contains two lipaemic samples which had basal paraxonase activities of 34 and $43 \mathrm{nmol} / \mathrm{min}$ $\mathrm{ml}$ and salt stimulated activities of 60 and $76 \mathrm{nmol} / \mathrm{min} / \mathrm{ml}$.

SERUM STUDIES

Cholinesterase activity

The serum cholinesterase method was based on that of Ellman et al, ${ }^{16}$ using butyrlthiocholine iodide $(7 \mathrm{mmol} / \mathrm{l})$ as substrate. The reaction was monitored at $405 \mathrm{~nm}$. The established reference range for this laboratory is $3 \cdot 0-9 \cdot 0$ $\mathrm{KU} / 1$

\section{Arylesterase activity}

Arylesterase activity $(\mathrm{mol} / \mathrm{min} / \mathrm{ml})$ was measured using the fixed incubation method of Lorentz et al. ${ }^{17}$ The reaction was carried out at $25^{\circ} \mathrm{C}$ using a TRIS acetate buffer $(100 \mathrm{mmol} / \mathrm{l}$, $\mathrm{pH} 7 \cdot 5)$ and phenyl acetate $(10 \mathrm{mmol} / \mathrm{l})$ as substrate. The reaction was monitored at $546 \mathrm{~nm}$.

\section{Paraoxonase activity}

Serum paraoxonase activity $(\mathrm{nmol} / \mathrm{min} / \mathrm{ml})$ was measured at $\mathrm{pH} 8.0$ using the method described by Mackness and Walker, ${ }^{18}$ incorporating a $10 \mathrm{mM}$ TRIS acetate buffer containing $2 \mathrm{mM}$ calcium chloride. The rate of hydrolysis of paraoxon was assessed by measuring the liberation of p-nitrophenol at $25^{\circ} \mathrm{C}$. The reaction was monitored at $412 \mathrm{~nm}$ without (basal activity) and with $\mathrm{NaCl}$ (salt stimulated activity) added to the substrate.

Paraoxonase phenotyping

The samples were phenotyped using the equations below.

(1) Per cent stimulation of paraoxonase activity by $1 \mathrm{M} \mathrm{NaCl}$ calculated as follows:

Paraoxonase activity with $1 \mathrm{M} \mathrm{NaCl}$ - Basal paraoxonase activity Basal paraoxonase activity

Sixty per cent stimulation is used as the dividing point between the non-salt stimulated A phenotype $(<60 \%)$ and the salt stimulated $B$ phenotypes $(>60 \%){ }^{19}$ This method cannot distinguish between $B$ and $A B$ phenotypes.

(2) Paraoxonase to arylesterase ratio:

$$
\underline{\text { Paraoxonase activity with } 1 \mathrm{M} \mathrm{NaCl}}
$$$$
\text { Arylesterase activity }
$$

The A phenotype was taken as a P:A ratio of $<2.5 \times 10^{3}$, the $\mathrm{AB}$ phenotype as a ratio of $>2.5$ and $<5.0 \times 10^{3}$ and the $B$ phenotype as $>5 \cdot 0 \times 10^{3} .{ }^{20}$
Red cell cholinesterase (acetylcholinesterase)

Red cell cholinesterase was measured using a method based on that of Ellman et $a l^{16}$ and adapted for use on the COBAS FARA (Roche Products Ltd, Welwyn Garden City, UK). The washed packed cells were lysed with saponin $(50 \mu \mathrm{l}$ cells in $1 \mathrm{ml}$ saponin $(100 \mathrm{mg} / \mathrm{dl}))$. Acetyl(-methyl)thiocholineiodide $(7 \mathrm{mM} / \mathrm{l})$ in a $0 \cdot 1 \mathrm{M}$ phosphate buffer $(\mathrm{pH} 7 \cdot 2)$ was used as substrate $^{21}$ and the thiocholine produced reacted with dithionitrobenzoate to give a yellow colour which was monitored at $412 \mathrm{~nm}$. The reaction was carried out at $37^{\circ} \mathrm{C}$. Ninety EDTA blood samples collected from a hospital and general practice population gave a range of $5 \cdot 4-11.9 \mathrm{KU} / 1$ (median $8 \cdot 1 \mathrm{KU} / 1$, quartiles $7 \cdot 5 \mathrm{KU} / 1$ and $8 \cdot 8 \mathrm{KU} / \mathrm{l})$.

\section{STATISTICS}

The Mann-Whitney U test was used to compare the results of MED samples with those of the controls.

\section{Results}

Basal paraoxonase, salt stimulated paraoxonase, serum cholinesterase, and red cell cholinesterase activities are presented in table 1. Subjects with MED were not significantly different from the control group for any of the enzymes measured. The phenotypes of the MED group were similar to the control group, as shown in tables $2 \mathrm{a}$ and $2 \mathrm{~b}$.

\section{Discussion}

Red cell cholinesterase, serum pseudocholinesterase and monocyte esterase are each diminished in vivo following exposure to organophosphate compounds. Monocyte esterase activity recovers rapidly when exposure ceases. ${ }^{1022}$ This investigation has proved that MED in our subjects was not caused by either current or recent exposure to organophosphate compounds because we found no difference in the activities of serum or red cell cholinesterases between our MED cohort and the control group. The paraoxonase phenotype was the same for both the control and MED groups. We found more of the non-A phenotypes in both groups than has been previously reported, ${ }^{23}$ but the number of subjects included in the study is small; the discrepancy in the number of A phenotypes shown in the control group by the two methods was probably be-

Table $2 a$ Paraoxonase phenotype as determined by per cent stimulation with $\mathrm{NaCl}$

\begin{tabular}{llll}
\hline & \multicolumn{2}{l}{ Phenotype } \\
\cline { 2 - 4 } & $A$ & $B$ \\
\hline MED & 4 & 7 & \\
Controls & 4 & 7 & \\
\hline Table 2b & Paraoxonase phenotype as determined by salt \\
stimulated paraoxonase activity/arylesterase activity
\end{tabular}


cause of the presence of two lipaemic serum samples giving a low basal paraoxonase activity.

Newcombe ${ }^{15}$ has suggested that exposure to organophosphates might add to lymphomagenic stress in subjects with MED. Certainly, chromosomal changes have been described in workers who are exposed to high levels of organophosphates ${ }^{25}$ and there is suggestive epidemiological evidence of an excess of lymphoma amongst these subjects. ${ }^{26}$ As it is possible to deduce from the reduction in the activities of plasma and red cell cholinesterases, and lymphocyte and monocyte esterases on exposure to organophosphates that these enzymes have a role in the detoxification of organophosphates, then it is reasonable to suggest that a constitutional lack of one of them might diminish the detoxification capacity of affected individuals and expose them to the deleterious effects of these compounds. However, an increase in the other normally occurring esterases might compensate for the effect of a single deficiency. Amplification of an esterase gene leading to organophosphate resistance has been described in insects ${ }^{27}$ and it has been suggested that omnivorous and herbivorous birds have developed a wider range of esterases than carnivorous birds in order to detoxify organophosphates which can contaminate plant foods. ${ }^{28}$ In this context, we have often noted unusually large and frequent esterase positive "dots" in lymphocytes of subjects with MED under standard staining conditions (unpublished observation). Alternatively, mutation may alter enzyme sensitivity to inhibitors. Pseudocholinesterase genes are subject to frequent point mutations and it has been suggested that this may represent a host selection response to ecological danger from cholinesterase inhibitors. ${ }^{29}$ One small study, however, has shown that variant pseudocholinesterases do not appear to have altered sensitivity to organophosphates. ${ }^{30}$ The molecular basis for MED is not known as yet, but it is probable that a lack of esterase activity is because of the presence of variant enzyme(s) which may in fact be equally sensitive/resistant to organophosphates. The suggestion that subjects with MED might be more susceptible to the ill effects of organophosphates may not be tenable. It is also possible that the major bodily function of monocyte esterase is unrelated to the properties of the active site which are recognised by the cytochemical esterase stain, but the accumulating evidence suggests that monocyte esterase function is at least influenced by the activity of this site. This study has shown, however, that exposure to organophosphates is not the cause of the inactivity of the site in our subjects.

The authors would like to thank Dr Michael Mackness for his help and advice and for allowing us the use of his laboratory help and advice and for allowing us the use of his laboratory We also thank Miss C Shiels and Mrs M Ferris for their expertise in preparing the manuscript.

1 Uphoff CC, Gignac SM, Metge K, Weili MA, Rainey FA, Kreutz M, et al. Expression of the monocyte-specific esterase gene in leukemia-lymphoma cell lines. Leukemia 1993; 7:58-62.

$2 \mathrm{Li} \mathrm{CY}$, Lam KW, Yam IT. Esterase in human leukocytes. 7 Histochem Cytochem 1973;21:1-12.

3 Drexler HG, Gaedicke G. Isoenzyme studies in human leukemia. 11. Carboxylic esterase (E.C.3.1.1.1.). Leukleukemia. 11. Carboxylic
emia Res 1983;5:599-609.

4 Markey GM, McCormick JA, Morris TCM, Alexander HD, Nolan L, Morgan LM, et al. Monocyte esterase deficiency in malignant neoplasia. $\mathcal{F}$ Clin Pathol 1990;43:282-6.

5 Markey GM, Curry RC, Swain D, Morris TCM, McCormick JA, Alexander HD, et al. Monocyte esterase deficiency in gastrointestinal cancer. $\mathcal{F}$ Clin Pathol 1993;46: 529-32.

6 Markey GM, Morris TCM, Alexander HD, Kyle A, Middleton D, Turner A, et al. Monocyte esterase? A factor involved in the pathogenesis of lymphoproliferative neoinvolved in the pathogenesis of

7 Bell AL, Markey GM, McCaigue MD, Middleton D, McCormick JA, Wilson AG, et al. Heredofamilial deficiency of monocyte esterase in patients with rheumatoid arthritis. Ann Rheum Dis 1992;51:668-70.

8 Becker-Follman J, Zschunke F, Parwaresch MR, Radzun HJ, Schererg G. Assignment of human monocyte/macrophage serine esterase 1 (HMSE1) to human chromosome 16q13q22.1 and its homologue to the proximal esterase cluster on mouse chromosome 8. Cytogenet Cell Genet 1991: A27057,1997.

9 Lee MJ, Waters HC III. Inhibition of monocyte esterase activity by organophosphate insecticides. Blood 1977;50: activity

10 Oehmichen $M$, Pedal L, Besserer $K$, Gencic $M$. Inhibition of non-specific leukocyte esterase activity. Absence of monocyte esterase activity due to phosphoric and thiophosphoric acid ester intoxication. Forensic Sci Int 1984; 25:181-9.

11 Mandel JS, Berlinger NT, Kay N, Connett J, Reape $M$. Organophosphate exposure inhibits non-specific esterase staining in human blood monocytes. Am F Ind Med 1989; 15:207-12.

12 McCormick JA, Markey GM, Morris TCM, Auld PW, Alexander HD. Lactoferrin inducible monocyte cytotoxicity defective in esterase deficient monocytes. $\mathrm{Br} \mathcal{7}$ toxicity defective in esterase

13 Oertel J, Hagner G, Kastner M, Huhn D. The relevance of alpha-napthyl acetate esterases to various monocyte functions. Br f Haematol 1985;61:717-26.

14 Esa AH, Warr GA, Newcombe DS. Immunotoxicity of organophosphorus compounds. Clin Immunol Immunopathol 1988;49:41-52.

15 Newcombe DS. Immune surveillance, organophosphorus exposure, and lymphomagenesis. Lancet 1992;339:539-41.

16 Ellman GL, Courtney D, Andres V, Featherstone ?. A new and rapid colorimetric determination of acetylcholinesterase activity. Biochem Pharmacol 1961;7:88-95.

17 Lorentz K, Flatter B, Augustin E. Arylesterase in serum. Elaboration and clinical application of a fixed incubation method. Clin Chem 1979;25:1714-20.

18 Mackness MI, Walker CH. Partial purification and properties of sheep serum A esterases. Biochem Pharmacol 1983; 32:2291-6.

19 Eckerson HW, Wyte CM, La Du BN. The human serum paraoxonase/arylesterase polymorphism. Am $\mathfrak{f}$ Hum Genet 1983;35:1126-38.

$20 \mathrm{La} \mathrm{Du} \mathrm{BN}$, Eckerson HW. The polymorphic paraoxonase/ arylesterase isoenzymes of human serum. Fed Proc 1989; 93:2338-41.

21 Meuling WJA, Jongen MJM, van Hemmen JJ. An automated method for the determination of acetyl and pseudo cholinesterase in hemolysed whole blood. Am f Ind Med 1992; 22:231-41.

22 Emmett EA, Lewis PG, Tanaka F, Bleeker M, Fox R, Darlington AC, et al. Industrial exposure to organophosphorus compounds. $\mathcal{F}$ Occup Med 1985;27:905-14.

$23 \mathrm{La} \mathrm{Du}$ BN. Human serum paraoxonase/arylesterase. In Kalow W, ed. Pharmacogenetics of drug metabolism. New York: Pergamon Press, 1992:51-91.

24 Haagen L, Brock A. A new automated method for phenotyping arylesterase (EC3.1.1.2) based on inhibition of enzymatic hydrolysis of 4-nitrophenyl acetate by phenyl acetate. Eur $¥$ Clin Chem Clin Biochem 1992;30:391-5.

25 Ruzieska P, Czeizel A, van Bao T, Szabo I. Human chromosome aberrations in acute organic phosphorus acid mosome aberrations in acute organic phosphorus acid

26 Alavanja MCR, Blair A, Masters NM. Cancer mortality in

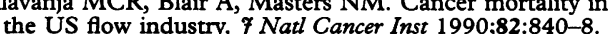
the US flow industry. $f$ Nat Cancer Inst $1990 ; 82: 840-8$

7 Mouchès C, Pasteur N, Berge JB, Hyrien O, Raymond M de Saint Vincent BR, et al. Amplication of an esterase gene is responsible for insecticide resistance in a $\mathrm{Ca}$ lifornian culex mosquito. Science 1986;233:778-80.

28 Thompson HM, Mackness MI, Walker CH, Hardy AR Species differences in avian serum $B$ esterases revealed by chromato focussing and possible relationships of esterase activity to pesticide toxicity. Biochem Pharmacol 1991;41 $1235-40$

29 Soreg H, Lapidot-Lipson, Zakut H. A role for cholinesterases in tumorigenesis. Cancer Cells 1991;3:511-16.

30 Kalow W, Davies RO. The activity of various esterase inhibitors towards human serum cholinesterase. Biochem Pharmacol 1958;1:183-92. 


\section{Correspondence}

\section{Job description of MLSOs}

Histopathologists and cytologists as a group tend to be obsessional individuals which in our work can be a useful trait but when this is taken to extreme degrees it becomes a disease (common sense is ignored and everyday life interfered with). This neurotic state is made much more serious when it is encouraged by bodies responsible for maintaining standards, The Royal College and the CPA. When Dr Tim Ashworth wrote to the $B M$ f suggesting that MLSOs should do all or most trimming and even report many histological specimens he caused a furore. ${ }^{1}$ When, in my view, the just as extreme idea that they should do nothing apart from reporting negative cervical smears and possibly loading endoscopic biopsy specimens into cassettes, is proposed by the College and policed by the CPA, there is silence. As a grass roots pathologist who (to comply with accreditation requirements) has just waded through a lake of negative urine cytology and sputa without a hint of a malignant cell I feel this silence should be broken.

A competent MLSO should be able to report a negative urine or sputum and pass on a doubtful case to a pathologist; this is surely easier than the screening of cervical smears. The overall responsibility is still the pathologist's for ensuring that this is done safely but in a service which is consultant based in most non-teaching hospitals it is a waste of consultant time to report this kind of material. I wrote to the CPA recently to confirm their position on this. My heart sank to learn, I quote, that these are "mainly diagnostic specimens" and that the "responsibility for reporting them lies with the pathologist". This was based on the Authoritative Guidelines for Histopathology Laboratories published by The Royal College of Pathologists in 1989! Are they really mainly diagnostic specimens or are they much more the equivalent of a full blood count carried out when a patient has a particular symptom complex? I think the latter. I know that quite a few of my colleagues at other hospitals are paying lip service to this accreditation requirement. This is dangerous medicolegally; if I put my name to a report it implies that I have looked at the slides carefully.

A lot has changed since 1989. The present policy is bizarre and should be reviewed urgently. Is it right that at a time when in other branches of medicine there is ever increasing delegation of responsibility, even the possibility that nurses will one day carry out endoscopies, we are heading in the opposite direction. I am very worried that pathology in its terror of occasional mistakes being made, which are after all inevitable even if all urines and sputa were reported by professors of pathology, is losing its way and is increasingly out of step with the rest of medicine. A profession afraid to delegate sensibly will eventually be forced to do so by others.

G M KONDRATOWICZ Consultant Histopathologist, Kidderminster General Hospital, Bewdley Road, Kidderminster Wors. DY11 6Rf

\section{Book review}

Human Tissue: Ethical and Legal Issues.

Working party on human tissue chaired by Professor Dame Rosalinde Hurley. (Pp 153; £10.00.) Published by and available from The Nuffield Council on Bioethics, 28 Bedford Square, London WC1B 3EG. ISBN 0 952270110

Advances in medical treatment, scientific research and biotechnology have highlighted public concern over a variety of ethical issues raised by the use of human tissue. For instance, questions have been raised regarding the sale of organs, the patenting of life forms and the commercial exploitation of products derived from the tissues of patients or research projects.

Quite rightly, society expects the human body and its parts to be treated with respect and that human tissue should not be used at will or abused, but in general has welcomed advances resulting in the use of human tissue in therapy, such as transplant surgery, and some of the developments resulting from genetic research. The potential of scientific advances for improvements in patient care is considerable, but raises many ethical and legal questions that affect us all. Some of the ethical challenges will be difficult to handle and there will be different opinions as to how they should be handled within different cultures.

The Nuffield Council on Bioethics decided to establish a working party, under the chairmanship of Professor Dame Rosalinde Hurley, to define the ethical and associated legal questions raised by the medical and scientific uses of human tissue. The terms of reference included current and prospective medical and scientific uses of sub-cellular structures, cells and their products, tissues and organs; to give some account of developments in research and exploitation of tissue, identifying current and potential benefits and difficulties; to identify and define ethical issues and questions of public policy and current practices arising from the use and exploitation of human tissue.

The report clarifies the current provisions of the law and highlights many areas requiring further debate in which further statutory provision or regulation may be required. It is clearly written and follows a logical sequence, including introduction, areas of public concern, definition, sources and uses of human tissue, ethical principles and legal matters, and concludes with a list of recommendations. The conclusions and recommendations include advice on the ethical principles in the use of human tissue, legal matters arising from the use of human tissue, guidance for consent procedures, guidance relating to constraints on commercial transactions, the responsibilities of medical intermediaries such as tissue banks that supply human tissue, the need for the government, together with other member states, to seek the adoption of a protocol to the European Patent Convention relating to patents in the area of human and animal tissue, and advice on safety and quality.

The Working Party concludes that organising the removal and supply of human tissue along commercial lines is unethical; that more should be done to encourage the concern of donors for others in the hope that more will come forward; that when tissue is removed in the course of medical treatment, consent to the treatment should cover any further uses of the tissue; including the registering of tissue banks and monitoring of their activity. Complex issues regarding the removal of tissue from living persons who are deemed legally incompetent and from children are highlighted, the present legality of which is uncertain. The authors recommend that any removal should be exceptional and limited to procedures that pose negligible risk and minimal burden, and that the Law Commission's proposals, which would permit non-therapeutic research on incompetent adults, subject to strict safeguards, should be enacted.

This report is timely and, in addition to its importance to all those involved in the provision of health care, medical research and teaching, should generate widespread interest and debate within the general public. The Working Party's advice, that relevant professional bodies should now ensure that their professional guidelines clearly establish the responsibilities of the increasing number of their members who will find themselves acting as medical intermediaries involved in the acquisition and supply of human tissue, must be accepted. I hope that this document stimulates worldwide debate involving the general public and, in particular, educational institutions. I strongly recommend it.

W R TIMPERLEY

\section{Notice}

\section{3th International Conference on Human Tumour Markers \\ fune 16-19 1996}

Sponsored by: International Academy of Tumor Marker Oncology (IATMO), Vienna

Organiser: Singapore Association of Clinical Biochemists

Topics for scientific sessions include: enzymology related to malignancy, clinical application of tumour markers, hormones and cancer, new instrumentation/methodology, and new developments in oncogenes and tumour biology.

The Conference will also feature free oral/ poster presentation sessions and an industrial exhibition.

Organising Committee Co-Chairmen: Dr It-Koon Tan/Dr Edward Jacob, Department of Pathology, Singapore General Hospital, Singapore. (Tel: (65) 321 4914; fax: (65) 222 6826.)

Secretariat: Academy of Medicine, Singapore, 16 College Road \#01-01, Singapore 0316. (Tel: (65) 223 8968; fax: (65) 225 5155.)

\section{Correction}

Organophosphates and monocyte esterase deficiency (F Clin Pathol 1995;48:768-70). An editorial error occurred in the Arylesterase activity subsection of the Methods section. The units for arylesterase activity are $\mu \mathrm{mol} / \mathrm{min} / \mathrm{l}$ and not $\mathrm{mol} / \mathrm{min} / \mathrm{ml}$ as printed. On $\mathrm{p} 768$, introduction, column 1 , line 21 , 16q3:22.1 should read 16q13-q22.1. 